\title{
Raloxifene Ameliorates Glucosamine-Induced Insulin Resistance in Ovariectomized Rats
}

\author{
Chung-Hwan Chen $1,2,3,4,5,6,7,8,9,+\left(\mathbb{D}\right.$, Tsung-Lin Cheng $1,3,10,+\left(\mathbb{D}\right.$, Chi-Fen Chang ${ }^{11}$, Hsuan-Ti Huang $1,2,3,4,5 \mathbb{D}$, \\ Sung-Yen Lin 1,2,3,4,5,6, Meng-Hsing Wu 12,13 $\mathbb{D}$ and Lin Kang 12,13,*(D)
}

1 Orthopaedic Research Center, College of Medicine, Kaohsiung Medical University, Kaohsiung 80701, Taiwan; hwan@kmu.edu.tw (C.-H.C.); junglecc@kmu.edu.tw (T.-L.C.); hthuang@kmu.edu.tw (H.-T.H.); sungyenlin@kmu.edu.tw (S.-Y.L.)

2 Department of Orthopedics, Kaohsiung Medical University Hospital, Kaohsiung Medical University, Kaohsiung 80701, Taiwan

3 Regeneration Medicine and Cell Therapy Research Center, Kaohsiung Medical University, Kaohsiung 80701, Taiwan

4 Departments of Orthopedics, College of Medicine, Kaohsiung Medical University, Kaohsiung 80701, Taiwan

5 Department of Orthopedics, Kaohsiung Municipal Ta-Tung Hospital, Kaohsiung Medical University, Kaohsiung 80145, Taiwan

6 Department of Healthcare Administration and Medical Informatics, Kaohsiung Medical University, Kaohsiung 80701, Taiwan

7 Institute of Medical Science and Technology, National Sun Yat-Sen University, Kaohsiung 80420, Taiwan

8 Graduate Institute of Animal Vaccine Technology, College of Veterinary Medicine, National Pingtung University of Science and Technology, Pingtung 912301, Taiwan

9 Graduate Institute of Materials Engineering, College of Engineering, National Pingtung University of Science and Technology, Pingtung 912301, Taiwan

check for

updates

Citation: Chen, C.-H.; Cheng, T.-L.; Chang, C.-F.; Huang, H.-T.; Lin, S.-Y.; Wu, M.-H.; Kang, L. Raloxifene

Ameliorates Glucosamine-Induced Insulin Resistance in Ovariectomized Rats. Biomedicines 2021, 9, 1114. https://doi.org/10.3390/

biomedicines 9091114

Academic Editor: Susan J. Burke

Received: 4 August 2021

Accepted: 24 August 2021

Published: 30 August 2021

Publisher's Note: MDPI stays neutral with regard to jurisdictional claims in published maps and institutional affiliations.

Copyright: (c) 2021 by the authors. Licensee MDPI, Basel, Switzerland. This article is an open access article distributed under the terms and conditions of the Creative Commons Attribution (CC BY) license (https:/ / creativecommons.org/licenses/by/ $4.0 /)$.
10 Department of Physiology, College of Medicine, Kaohsiung Medical University, Kaohsiung 80701, Taiwan

11 Department of Anatomy, School of Medicine, China Medical University, Taichung 40402, Taiwan; cfchang@mail.cmu.edu.tw

12 Department of Obstetrics \& Gynecology, College of Medicine, National Cheng Kung University, Tainan 70101, Taiwan; mhwu68@mail.ncku.edu.tw

13 Department of Obstetrics and Gynecology, National Cheng Kung University Hospital, College of Medicine, National Cheng Kung University, Tainan 70101, Taiwan

* Correspondence: kanglin@mail.ncku.edu.tw; Tel.: +886-6-276-6685

$+\quad$ These authors contributed equally to this work.

Abstract: Osteoarthritis (OA) and osteoporosis (OP) are common among older women, especially postmenopausal women. Glucosamine $(\mathrm{GlcN})$ is a common medication for OA, but it may induce insulin resistance and $\beta$-cell dysfunction, especially if ovarian hormones are lacking. Raloxifene (RLX) is a selective estrogen receptor modulator and also an OP drug. Previously, we found that estrogen could improve GlcN-induced insulin resistance in ovariectomized (OVX) rats. Here, we further hypothesized that RLX, similarly to estrogen, can ameliorate GlcN-induced insulin resistance in OVX rats. We used GlcN to induce insulin resistance in OVX rats as a model for evaluating the protective effects of RLX in vivo. We used a pancreatic $\beta$-cell line, MIN-6, to study the mechanisms underlying the effect of RLX in GlcN-induced $\beta$-cell dysfunction in vitro. Increases in fasting plasma glucose, insulin, and homeostasis model assessments of insulin resistance in OVX Sprague Dawley rats treated with GlcN were reversed by RLX treatment ( $n=8$ in each group). Skeletal muscle GLUT-4 increased, liver PEPCK decreased, pancreatic islet hypertrophy, and $\beta$-cell apoptosis in OVX rats treated with GlcN was ameliorated by RLX. The negative effects of GlcN on insulin secretion and cell viability in MIN-6 cells were related to the upregulation of reticulum (ER) stress-associated proteins (C/EBP homologous protein, phospho-extracellular signal-regulated kinase, phospho-cJunN-terminal kinase), the expression of which was reduced by RLX. Pretreatment with estrogen receptor antagonists reversed the protective effects of RLX. GlcN can induce insulin resistance, $\beta$-cell dysfunction, and apoptosis in OVX rats and increase ER stress-related proteins in $\beta$-cells, whereas RLX can reverse these adverse effects. The effects of RLX act mainly through estrogen receptor $\alpha$; therefore, RLX may be a candidate drug for postmenopausal women with OA and OP. 
Keywords: apoptosis; endoplasmic reticulum stress; glucosamine; pancreatic $\beta$-cell dysfunction; ovariectomy; raloxifene

\section{Introduction}

Metabolic syndrome and type 2 diabetes mellitus (T2DM) are prevalent health problems [1]. Insulin resistance (IR) is a hallmark of T2DM and metabolic syndrome, which have higher prevalence in postmenopausal women than in premenopausal women. Osteoarthritis (OA) is also prevalent in postmenopausal women [2]. T2DM, with its related chronic hyperglycemia and IR, induces possibly pathogenic effects in OA through oxidative stress and chronic low-grade inflammation [3]. Glucosamine (GlcN) is a nutritional supplement widely used for OA $[4,5]$. However, studies have reported that GlcN affects glucose tolerance and IR $[3,6]$. GlcN inhibits the insulin production of pancreatic $\beta$-cells $[7,8]$. The implications of clinical data regarding $\mathrm{GlcN}$ and glucose metabolism are conflicting. Some clinical studies have observed harmful effects of GlcN on glucose metabolism $[9,10]$, whereas others have reported no effects $[11,12]$.

Ovarian estrogen, $17 \beta$-estradiol $\left(\mathrm{E}_{2}\right)$, has ameliorated both insulin sensitivity and insulin production in animal and human studies $[13,14]$. The risk of T2DM increased after ovariectomy in an animal study, whereas estrogen application ameliorated T2DM and enhanced insulin sensitivity [15]. In pancreatic $\beta$-cells, $E_{2}$ can ameliorate glucolipotoxicity, oxidative stress, and apoptosis $[14,16]$. Estrogen receptors can regulate the function and survival of $\beta$-cells [17], although estrogen use is associated with an increased risk of various cancers [18].

Selective estrogen receptor modulators (SERMs) act on estrogen receptors with agonist or antagonist activity, depending on the tissue type. Raloxifene (RLX) is an SERM used for the treatment of postmenopausal osteoporosis (OP) because of its activity as an estrogen receptor agonist in bone [19-28]. The effect of RLX can be tissue- or species-specific [29]. One study using a pancreatic $\beta$-cell line (INS- 1 cells) demonstrated that RLX behaves as both an estrogen receptor antagonist through nuclear estrogen response element-dependent actions and as an estrogen receptor agonist by suppressing triglyceride accumulation [30]. The endoplasmic reticulum (ER) regulates intracellular calcium concentrations and protein folding and trafficking [31-34]. ER stress, the disruption of these ER functions, is related to T2DM in humans [35-37]. ER stress can be induced by GlcN and cause cell death [38,39]. In our previous study, we demonstrated that GlcN-induced IR in ovariectomized (OVX) rats was related to increased pancreatic islet size [40]. We also observed the protective effects of $E_{2}$ in GlcN-induced pancreatic $\beta$-cell dysfunction [41]. The rescue effects of RLX in GlcN-induced IR and pancreatic $\beta$-cell dysfunction have not been reported. In the current study, we used OVX rats treated with GlcN to induce IR and studied the protective effects of RLX in vivo. We also used pancreatic $\beta$-cell lines, MIN-6 cells, to study the protection and underlying mechanisms of RLX in GlcN-induced $\beta$-cell dysfunction in vitro.

\section{Materials and Methods}

\subsection{Ethics Statement}

All procedures were performed in accordance with the Institutional Guidelines for Animal Care of National Cheng Kung University, the Use of Laboratory Animals of the National Institutes of Health, and the guidelines of the Animal Welfare Act.

\subsection{Experimental Animals}

Twelve-week-old Female Sprague Dawley rats were purchased from the Animal Center of National Cheng Kung University Medical College and housed under standard laboratory conditions with free access to food and water. After acclimation, the rats were randomly allocated to one of 5 treatments: (1) sham operation (Sham group); (2) sham with $750 \mathrm{mg} / \mathrm{kg} / \mathrm{d}$ GlcN (Sigma-Aldrich, St. Louis, MO, USA) intraperitoneally (ip) injected 
for 14 days (Sham + GlcN group); (3) ovariectomy (OVX group); (4) ovariectomy with $750 \mathrm{mg} / \mathrm{kg} / \mathrm{d}$ GlcN ip treated for 14 days (OVX + GlcN group); or (5) ovariectomy with $750 \mathrm{mg} / \mathrm{kg} / \mathrm{d}$ GlcN ip treated for 14 days with subcutaneous RLX at $0.5 \mathrm{mg} / \mathrm{kg} / \mathrm{d}$ (Sigma Chemical Co., St. Louis, MO, USA; OVX + GlcN + RLX group; $n=8$ in each group). Surgeries were performed under ip administered sodium pentobarbital (Sigma-Aldrich) anesthesia through bilateral lower back skin incisions [40-45]. Twelve weeks after the surgery, GlcN was administered for two weeks [40,41,45].

\subsection{Intraperitoneal Glucose Tolerance Test}

An intraperitoneal glucose tolerance test (IPGTT) was administered with the rats fasted for $6 \mathrm{~h}$ after all of the treatments were completed. Blood samples for the measurement of plasma glucose and insulin were drawn from the femoral vein before glucose loading ( $1 \mathrm{mg} / \mathrm{kg}$, ip) at baseline (time 0). Blood samples were obtained at 30, 60, 90, and $120 \mathrm{~min}$ after glucose loading $[40,41,45]$.

\subsection{Plasma Glucose and Insulin Concentrations}

Plasma glucose levels were evaluated by a commercial kit reagent for glucose (Biosystems SS, Barcelona, Spain) by an analyzer (Quik-Lab, Elkhart, IN, USA). Insulin concentration was evaluated by an insulin enzyme-linked immunosorbent assay (ELISA) kit (Mercodia AB, Uppsala, Sweden), as described previously [40,45].

\subsection{Determination of IR in Rats}

IR and $\beta$-cell function were assayed using homeostasis model assessments of IR (HOMA-IR). The glucose-insulin index and clinical HOMA-IR were determined to evaluate IR and compare groups after the concentrations of plasma glucose and insulin were measured. The glucose-insulin index was calculated as the product of the glucose and insulin areas under the curve $($ AUCs). HOMA-IR $=[$ fasting glucose $(\mathrm{mmol} / \mathrm{L})] \times[$ fasting insulin $(\mathrm{pmol} / \mathrm{mL})] / 22.5[40,45]$.

\subsection{Measurement of Islet Size}

All pancreases were immersed in phosphate-buffered saline (PBS) containing $10 \%$ formaldehyde $(v / v)$ and kept at $4{ }^{\circ} \mathrm{C}$ for 2 days. After dehydration, the specimens were fixed in paraffin. The specimens were sliced into $5 \mu \mathrm{m}$ thick sections with $50 \mu \mathrm{m}$ distances; then, hematoxylin and eosin staining was performed. For each staining, more than three serial sections were used. The area of each islet was decided by Image-Pro Plus (Media Cybernetics, Inc., Rockville, MD, USA) with a total of 210-230 islets in each section [40,45].

2.7. Immunofluorescence Stains for Insulin and Terminal Deoxynucleotidyl Transferase dUTP Nick End-Labeling in Pancreatic Islets

Sequential $5 \mu \mathrm{m}$ thick pancreas sections around $2 \times 1 \mathrm{~cm}^{2}$ were immunostained for transferase dUTP nick end-labeling (TUNEL), insulin, and DAPI. The immunofluorescence staining intensity was quantified using Image-Pro Plus (Media Cybernetics, Inc., Rockville, MD, USA) [41,46-48].

\subsection{Western Blot Analysis for PEPCK in the Liver and GLUT-4 in the Soleus Muscle}

The livers and soleus muscles were harvested immediately after the rats were killed, as described previously [40,45]. In brief, the tissues were washed with cold PBS and cut into 200-300 mg portions. After homogenization of the liver and soleus muscle, the homogenates $(50 \mu \mathrm{g})$ were separated through sodium dodecyl sulfide-polyacrylamide gel electrophoresis, and Western blot analysis was performed using either an anti-rat glucose transport protein subtype 4 (GLUT-4) antibody (R\&D system, Inc., Minneapolis, MN, USA) (1:1000) in the soleus muscle or an anti-rat phosphoenolpyruvate carboxykinase (PEPCK) antibody (R\&D system, Inc., Minneapolis, MN, USA) (1:1000) in liver tissue. 


\subsection{Cell Culture and Compound Stimulation}

MIN-6 cells were kept in a monolayer culture at $37^{\circ} \mathrm{C}$ and $5 \%(v / v) \mathrm{CO}_{2}$ in Dulbecco's modified Eagle's medium (DMEM) supplemented with $10 \%(v / v)$ fetal bovine serum (FBS), $1.0 \times 10^{5} \mathrm{U} / \mathrm{L}$ penicillin, and $100 \mathrm{~g} / \mathrm{L}$ streptomycin. MIN-6 cells were incubated with RLX 1 at $\mu \mathrm{mol} / \mathrm{L}$ (Sigma Chemical Co.) [30], ICI 182,780 (antagonist to both estrogen receptor $\alpha$ and estrogen receptor $\beta$, Tocris, Ballwin, MO, USA) at $1 \mu \mathrm{mol} / \mathrm{L}$, and methyl-piperidinopyrazole (MPP, antagonist specific to estrogen receptor $\alpha$, Tocris Cookson, Ellisville, MO, USA) at $1 \mu \mathrm{mol} / \mathrm{L}$, as indicated, for $72 \mathrm{~h}$. After estrogen receptor ligand treatment, the cells were treated with GlcN (Sigma Chemical Co.) at $10 \mathrm{mmol} / \mathrm{L}$ for $6 \mathrm{~h}$ before assessment in the following experiments.

\subsection{Extracellular Insulin Levels}

The MIN-6 cells were incubated in 6-well plates $\left(1.0 \times 10^{4}\right.$ cells/well $)$ with $1 \mu \mathrm{mol} / \mathrm{L}$ ICI 182,780 or $1 \mu \mathrm{mol} / \mathrm{L}$ MMP for $1 \mathrm{~h}$ in high-glucose $(4.5 \mathrm{~g} / \mathrm{L})$ DMEM if needed, and then exposed to $1 \mu \mathrm{mol} / \mathrm{L}$ RLX for $24 \mathrm{~h}$. The cells were transferred to low-glucose $(1 \mathrm{~g} / \mathrm{L})$ DMEM with $1 \mu \mathrm{mol} / \mathrm{L}$ RLX for another $24 \mathrm{~h}$. After the supernatant was removed, the cells were washed twice with PBS and treated with $10 \mathrm{mmol} / \mathrm{L}$ GlcN for half an hour, and then exposed to glucose $(5.5 \mathrm{mmol} / \mathrm{L})$ for another half an hour. The insulin in the supernatant was assayed by an insulin ELISA kit (Mercodia AB, Uppsala, Sweden).

\subsection{Cell Viability Analysis}

MIN-6 cells were plated in 96-well plates $\left(1.0 \times 10^{4}\right.$ cells/well). The effects of RLX on the viability of GlcN -treated MIN-6 cells were evaluated by MTT assay. After a 1-day culture, the cells were treated with RLX, GlcN, ICI 182,780, and MPP as mentioned, and an MTT solution was subsequently used. The precipitates were dissolved in DMSO, and the absorbance was evaluated by an ELISA reader (Thermo Molecular Devices Co., Union City, CA, USA) at $570 \mathrm{~nm}$ after a $4 \mathrm{~h}$ culture. The cell viability ratio was calculated as follows:

$$
\text { Inhibitory ratio }(\%)=[(\mathrm{OD} \text { control }-\mathrm{OD} \text { treated }) / \mathrm{OD} \text { control }] \times 100
$$

\subsection{Western Blot Analysis for Protein Expression Related to ER Stress}

MIN-6 cells were treated as described in the preceding sections, and then proteins were harvested from the cell lysates after being treated with lysis buffer. We used $10 \%(w / v)$ sodium dodecyl sulfate-polyacrylamide gel electrophoresis to separate the protein lysates $(50 \mu \mathrm{g})$. Western blot analysis was performed by antibodies against C/EBP homologous protein (CHOP), phospho-extracellular signal-regulated kinase (p-ERK), phospho-c-JunNterminal kinase (p-JNK), and $\beta$-actin antibodies (Santa Cruz Biotechnology, Santa Cruz, CA, USA). The blots were treated with secondary antibodies. After washing, the blots were developed using the ECL Western blotting system (R\&D system, Inc., Minneapolis, MN, USA) and quantified through laser densitometry.

\subsection{Statistical Analysis}

The in vivo data are expressed as the mean \pm standard error of mean (SEM) for the number $(n)$ of animals in each group as indicated in the Methods. Each in vitro experiment was repeated $(n) 3$ or more times, and the data are expressed as mean \pm SEM. Statistical differences among groups were determined using the Friedman test in IPGTT and one-way analysis of variance in GLUT-4, PEPCK, TUNEL and the sizes of pancreatic islets. Dunnett range post hoc comparisons were used to determine the source of significant differences where appropriate $[40,45]$. A $p$ value $<0.05$ was considered significant.

\section{Results}

\subsection{RLX Ameliorated Fasting Glucose, Insulin, and HOMA-IR in the OVX + GlcN Rats}

The OVX + GlcN group (144 $\pm 7.8 \mathrm{mg} / \mathrm{dL})$ presented higher fasting glucose levels than that in the Sham $(120 \pm 4.2 \mathrm{mg} / \mathrm{dL})$, Sham + GlcN $(121 \pm 1.2 \mathrm{mg} / \mathrm{dL})$, OVX 
$(117 \pm 1.7 \mathrm{mg} / \mathrm{dL})$, and OVX + GlcN $+\operatorname{RLX}(117 \pm 4.9 \mathrm{mg} / \mathrm{dL})$ groups $(p<0.01) . \operatorname{RLX}$ significantly reduced fasting glucose level in the OVX rats (Figure 1A). In addition, the OVX + GlcN group (649 \pm 117 pmol/L) exhibited higher fasting plasma insulin level than that in all other groups $(p<0.001$; Figure $1 B)$. The OVX + GlcN group also exhibited higher fasting HOMA-IR $(33.5 \pm 6.6)$ than that in all other groups $(p<0.001$; Figure $1 C)$. RLX significantly reduced fasting plasma glucose, insulin levels ( $245 \pm 57 \mathrm{pmol} / \mathrm{L})$, and HOMA-IR $(10.6 \pm 2.6)$ in the OVX + GlcN rats.

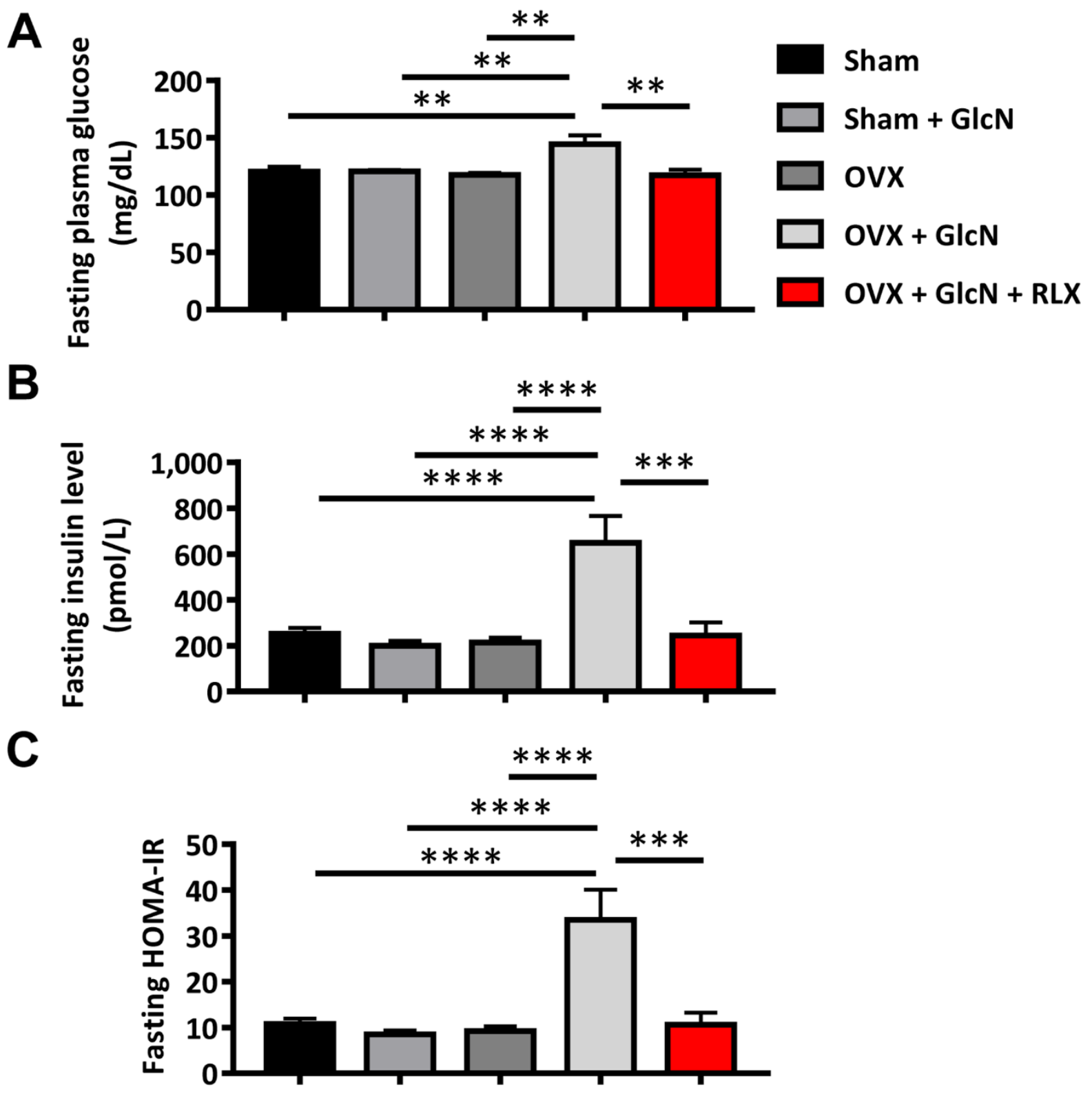

Figure 1. Levels of fasting glucose, insulin, and HOMA-IR (at time 0). The rats were randomly allocated to 5 treatments: (1) sham operation (Sham group), (2) sham with $750 \mathrm{mg} / \mathrm{kg} / \mathrm{d}$ GlcN intraperitoneally (ip) injected for 14 days (Sham + GlcN group), (3) ovariectomy (OVX group), (4) ovariectomy with $750 \mathrm{mg} / \mathrm{kg} / \mathrm{d}$ GlcN ip injected for 14 days (OVX+GlcN group), or (5) ovariectomy with $750 \mathrm{mg} / \mathrm{kg} / \mathrm{d}$ GlcN ip injected for 14 days with subcutaneous RLX at $0.5 \mathrm{mg} / \mathrm{kg} / \mathrm{d}$. ( $n=8$ in each group). (A) The OVX + GlcN group exhibited higher fasting glucose than that in all other groups. RLX can significantly reduce fasting glucose levels in OVX rats. (B) The OVX + GlcN group exhibited higher fasting plasma insulin than that in all other groups. (C) RLX can significantly reduce fasting HOMA-IR in GlcN-treated OVX rats. ${ }^{* *} p<0.01$; ${ }^{* * *} p<0.001 ;{ }^{* * * *} p<0.0001$. 
3.2. RLX Ameliorated Insulin, Glucose, Glucose-Insulin Index, and HOMA-IR in Plasma during IPGTT in the OVX + GlcN Rats

The OVX + GlcN group exhibited elevated plasma glucose level (all $p<0.01$ ) than that in all other groups at 30,60,90, and 120 min after glucose loading. Although the levels of glucose in the OVX $+\mathrm{GlcN}+\mathrm{RLX}$ group were higher than those in the three other groups (Sham, Sham + GlcN, OVX), the difference did not reach statistical significance (Figure 2A). In addition, the OVX + GlcN group also exhibited significantly higher AUC for the plasma glucose concentrations in the IPGTT than that in all other groups (Figure 2B). After glucose loading, the OVX + GlcN group exhibited significantly higher plasma insulin levels at 30, 60,90 , and 120 min than that in all other groups (all $p<0.001$; Figure 2C). The OVX + GlcN group demonstrated higher AUC for plasma insulin concentration (Figure 2D; $p<0.001$ ) than that in all other groups. The OVX + GlcN group also exhibited elevated HOMA-IR $(p<0.001$; Figure 2E). The glucose and insulin AUCs determine the glucose-insulin index. Only the OVX + GlcN group exhibited higher glucose-insulin index $(p<0.001$; Figure 2F). RLX reduced HOMA-IR and the glucose-insulin index nearly to the levels in the Sham group, as determined from the IPGTT. In addition to reducing fasting glucose, insulin, and HOMA-IR, RLX significantly reduced plasma glucose, insulin levels, and HOMA-IR to nearly the levels in the Sham group, as determined from the IPGTT.
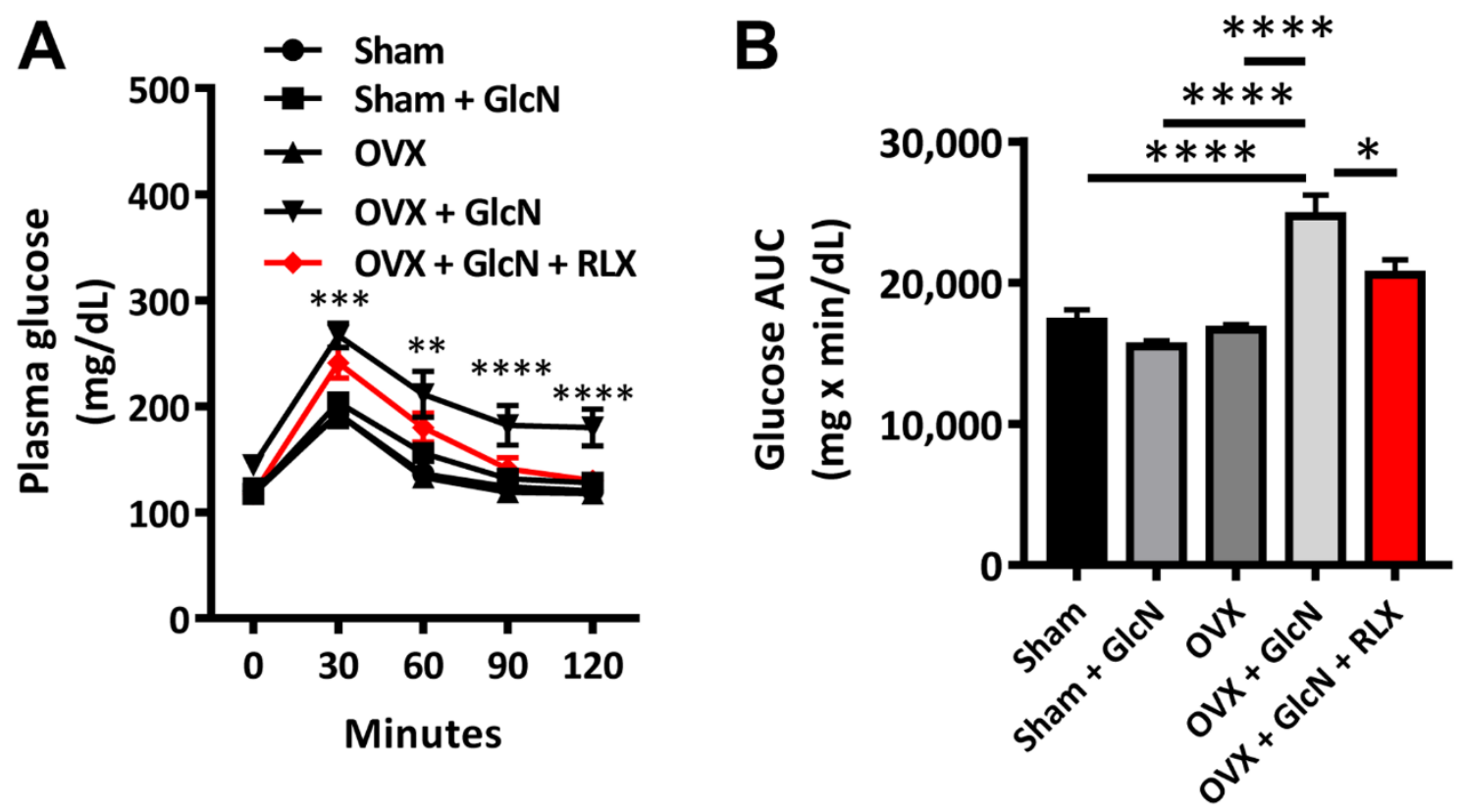

Figure 2. Cont. 

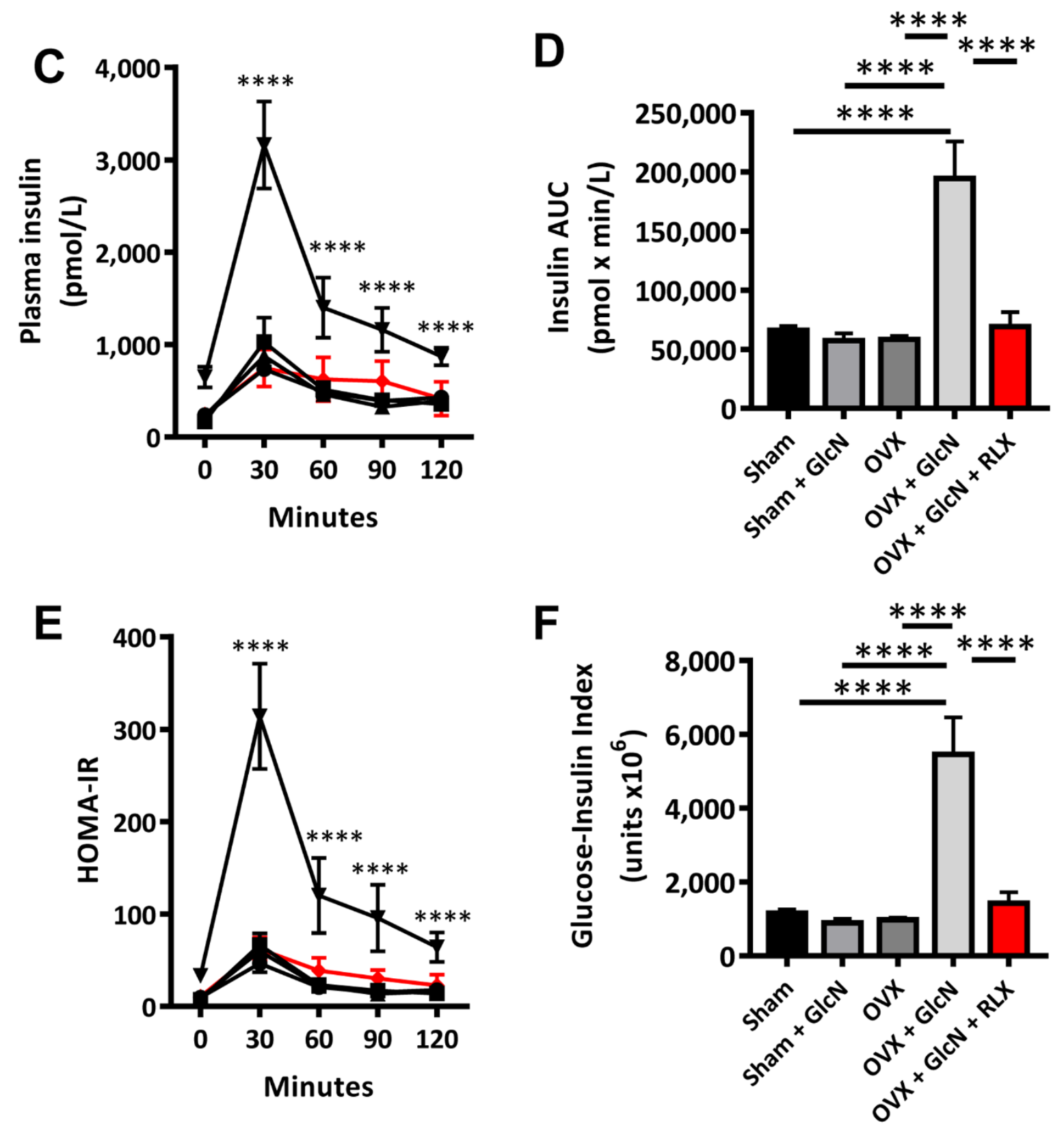

Figure 2. Levels and AUCs of plasma glucose, insulin, and HOMA-IR and glucose-insulin index in the IPGTT. The rats were randomly allocated to 5 treatments: (1) sham operation (Sham group), (2) sham with $750 \mathrm{mg} / \mathrm{kg} / \mathrm{d}$ GlcN intraperitoneally (ip) injected for 14 days (Sham + GlcN group), (3) ovariectomy (OVX group), (4) ovariectomy with $750 \mathrm{mg} / \mathrm{kg} / \mathrm{d} \mathrm{GlcN}$ ip injected for 14 days (OVX+GlcN group), or (5) ovariectomy with $750 \mathrm{mg} / \mathrm{kg} / \mathrm{d}$ GlcN ip injected for 14 days with subcutaneous RLX at $0.5 \mathrm{mg} / \mathrm{kg} / \mathrm{d}$. ( $n=8$ in each group). (A) The OVX + GlcN group exhibited elevated plasma glucose levels over all other groups at 30, 60, 90, and 120 min after glucose loading. Although the level of glucose in the OVX + GlcN + RLX group was higher than that in the other 4 groups, the difference did not reach statistical significance. (B) The OVX + GlcN group exhibited higher AUC for plasma glucose concentrations in the IPGTT than that in all other groups. RLX reduced the glucose AUC to nearly the level of the Sham group. (C) After glucose loading, the OVX + GlcN group demonstrated higher plasma insulin levels at 30, 60, 90, and $120 \mathrm{~min}$ than that in all other groups. (D) The OVX + GlcN group exhibited higher AUCs for plasma insulin concentrations than that in all other groups. RLX reduced the glucose-insulin index and the insulin AUC nearly to the levels in the Sham group. (E) Only the OVX + GlcN group exhibited higher HOMA-IR. The HOMA-IR of the 4 other groups exhibited no significant differences in the IPGTT. (F) The OVX + GlcN group demonstrated a higher glucose-insulin index. RLX reduced the glucose-insulin index to nearly the level in the Sham group. ${ }^{*} p<0.05 ;{ }^{* *} p<0.01 ;{ }^{* * *} p<0.001 ;{ }^{* * *} p<0.0001$. 


\section{3. $R L X$ Decreased Islet Size in the OVX + GlcN Rats}

The pancreatic islets in the Sham and Sham + GlcN groups were nearly the same size. The size of the pancreatic islets in the OVX group enlarged significantly and further increased in the $\mathrm{OVX}+\mathrm{GlcN}$ group; these results suggest that islet hyperplasia compensated for the initial IR $(p<0.001)$. RLX treatment decreased the pancreatic islets size in the OVX + GlcN rats to the size of those in the OVX group ( $p<0.01$; Figure $3 \mathrm{~A})$.

A
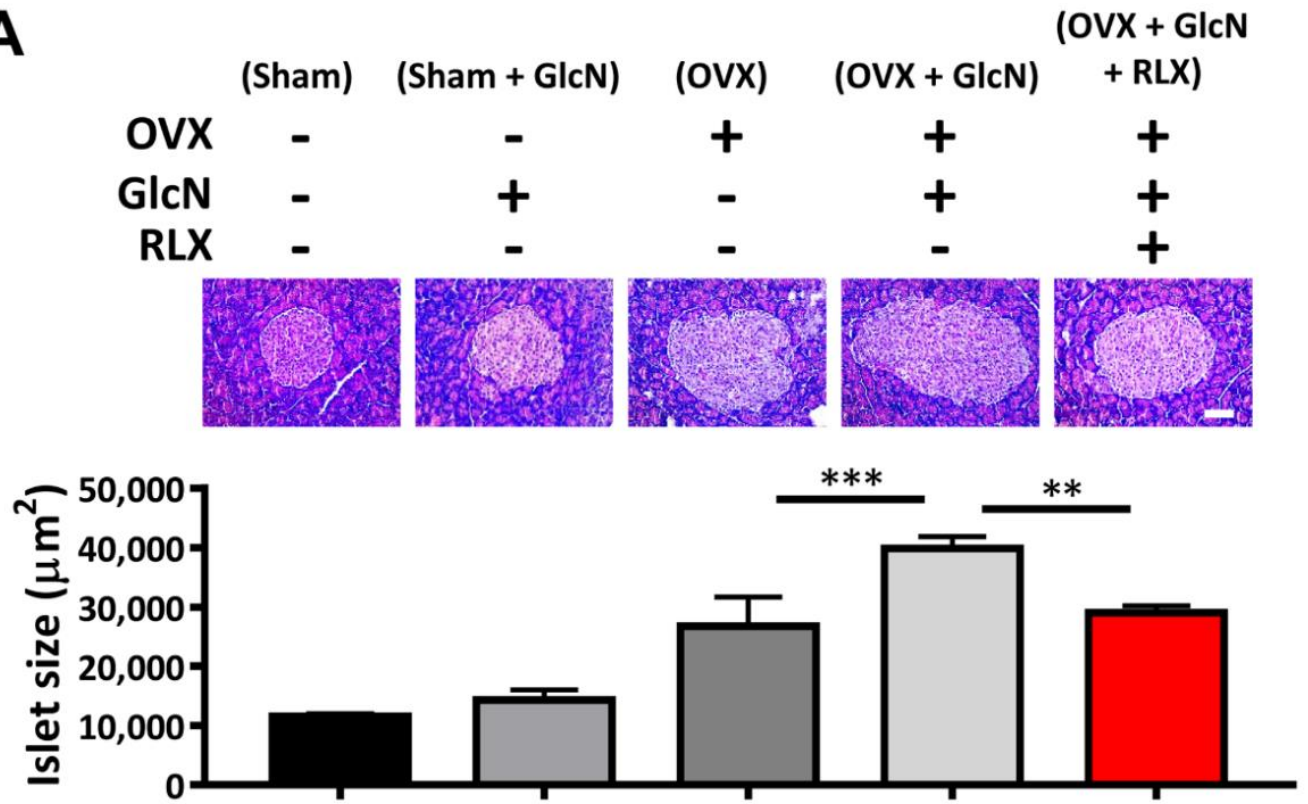

B

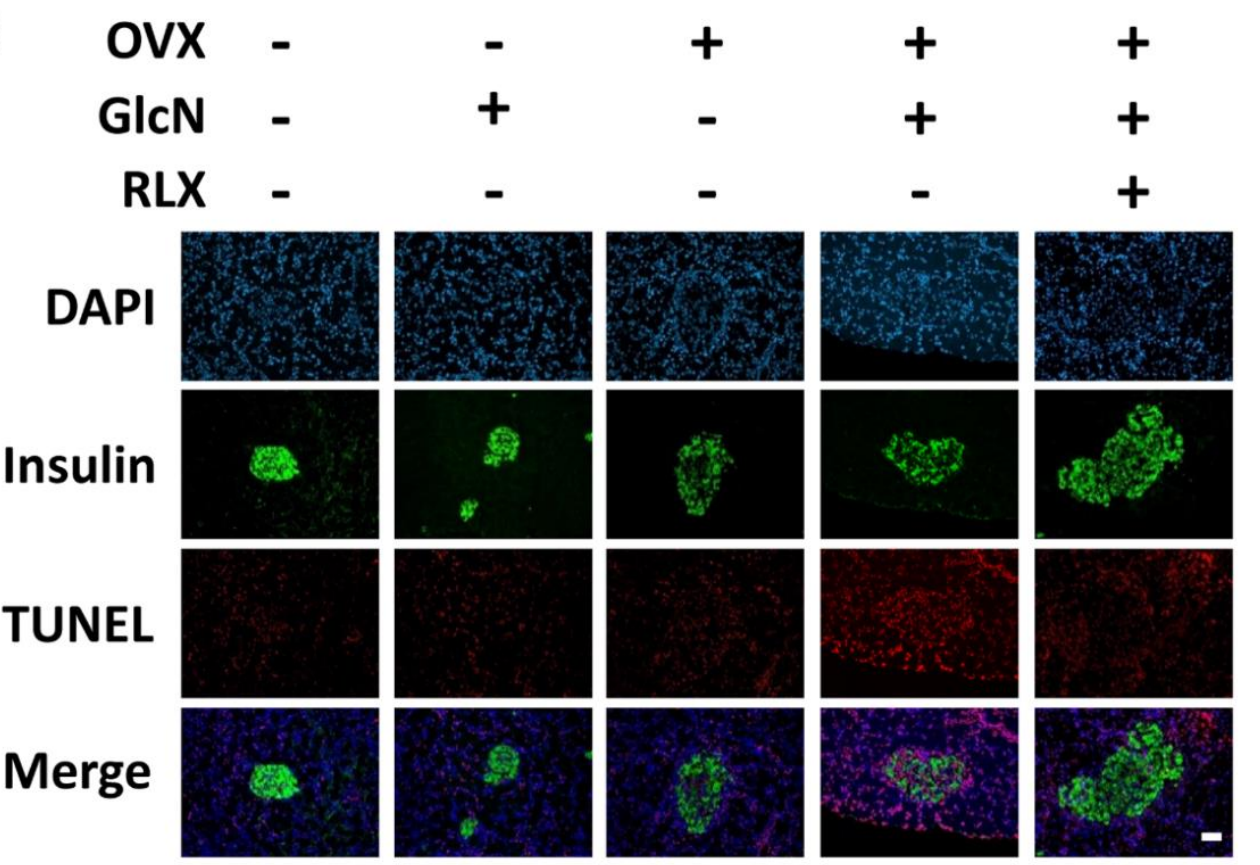

Figure 3. Cont. 


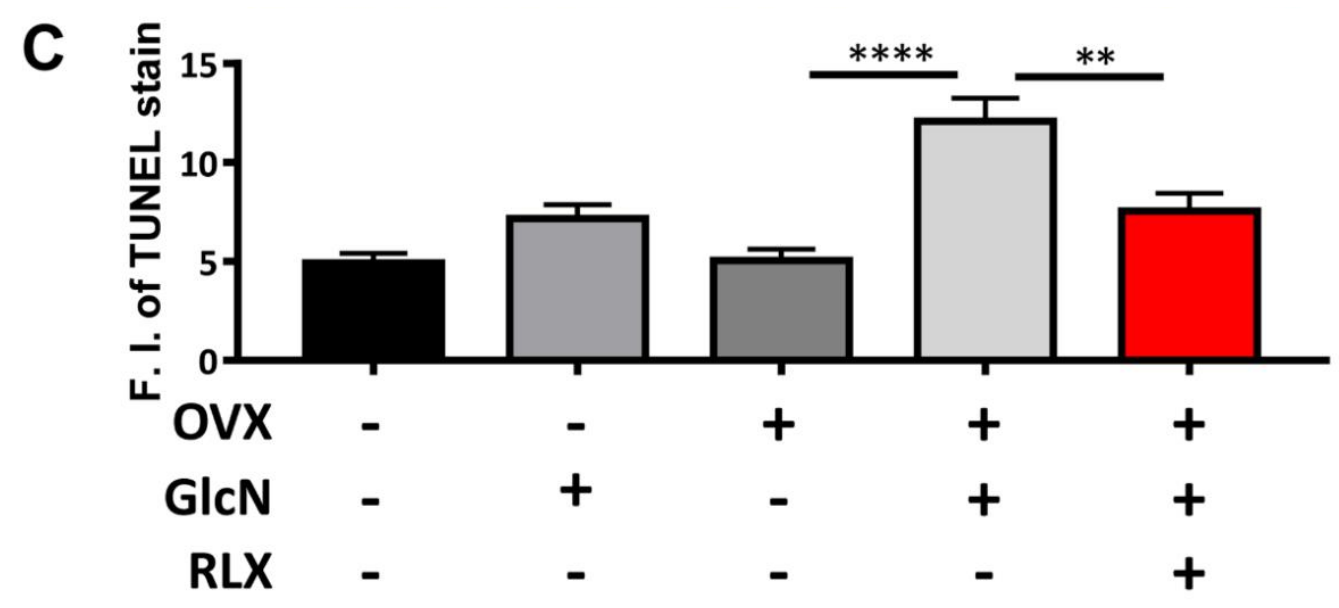

Figure 3. Islet size, immunofluorescence stains, and the quantification of insulin and TUNEL in rat pancreatic islets. The rats were randomly allocated to 5 treatments: (1) sham operation (Sham group), (2) sham with $750 \mathrm{mg} / \mathrm{kg} / \mathrm{d}$ GlcN intraperitoneally (ip) injected for 14 days (Sham + GlcN group), (3) ovariectomy (OVX group), (4) ovariectomy with $750 \mathrm{mg} / \mathrm{kg} / \mathrm{d}$ GlcN ip injected for 14 days (OVX+GlcN group), or (5) ovariectomy with $750 \mathrm{mg} / \mathrm{kg} / \mathrm{d}$ GlcN ip injected for 14 days with subcutaneous RLX at $0.5 \mathrm{mg} / \mathrm{kg} / \mathrm{d}$. ( $n=8$ in each group). (A) The size of pancreatic islets of all groups. Pancreatic islets were nearly the same size in the Sham and Sham + GlcN groups. The size of the pancreatic islets markedly increased in the OVX group and increased further in the OVX + GlcN group, suggestive of islet hyperplasia compensating for IR. RLX treatment significantly reduced the size of the pancreatic islets in the OVX+GlcN rats to nearly the size in the OVX group. (Scale bar $=50 \mu \mathrm{m})(\mathbf{B})$ Immunofluorescence stains for TUNEL and insulin in pancreatic islets of all groups. Ovariectomy and GlcN reduced the immunofluorescence staining intensity for insulin in pancreatic islets; this intensity further decreased in the OVX+GlcN group. Treatment with RLX in OVX+GlcN rats increased the staining intensity of insulin. No difference was present among the OVX, GlcN, and Sham groups in apoptotic cell proportions as determined through TUNEL staining. (Scale bar $=50 \mu \mathrm{m})(\mathrm{C})$ Quantification of immunofluorescence stains for TUNEL in rat pancreatic islets. No difference existed among the OVX, GlcN, and Sham groups in the proportions of apoptotic cells. The proportion of apoptotic cells increased significantly in the OVX+GlcN group $(12.09 \% \pm 1.17 \%)$, whereas RLX reduced the proportion of apoptotic cells in the OVX+GlcN group (7.549\% $\pm 0.90 \%)$. Each bar represents the mean $\pm \operatorname{SEM}(n=8-10$ in each group). ** $p<0.01$; $^{* * *} p<0.001$; $^{* * * *} p<0.0001$.

\subsection{RLX Decreased Pancreatic Islet Apoptosis in TUNEL Stain in the OVX + GlcN Rats}

Immunofluorescence staining for insulin as a marker of pancreatic islets and TUNEL staining to evaluate the level of apoptosis (Figure 3B) were performed. No difference was observed in apoptotic cells among the OVX, GlcN, and Sham groups in TUNEL staining. The proportion of apoptotic cells increased significantly in the OVX + GlcN group (12.09\% $\pm 1.17 \%$ ), whereas RLX reduced the number of apoptotic cells in the OVX + GlcN group (7.549\% \pm 0.90\%; Figure 3C).

3.5. RLX Increased the Expression of PEPCK in the Liver and Decreased the Expression of GLUT-4 in the Soleus Muscle in the OVX + GlcN Rats

OVX rats given GlcN presented with more PEPCK in the liver and less GLUT-4 expression in the soleus muscle. RLX treatment reversed these effects. No significant difference was observed in PEPCK or GLUT-4 expression among the Sham + GlcN, OVX, Sham, and OVX + GlcN + RLX groups ( $p<0.05$; Figure 4$)$. 
A

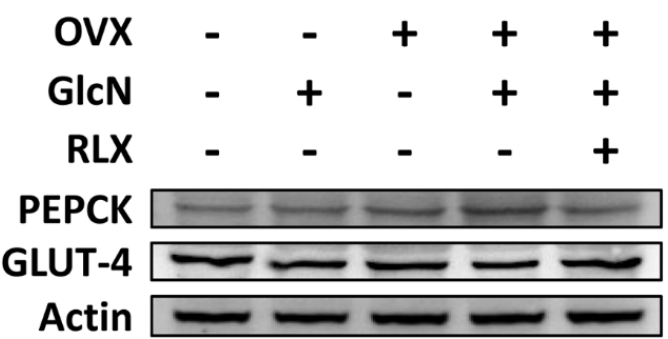

B

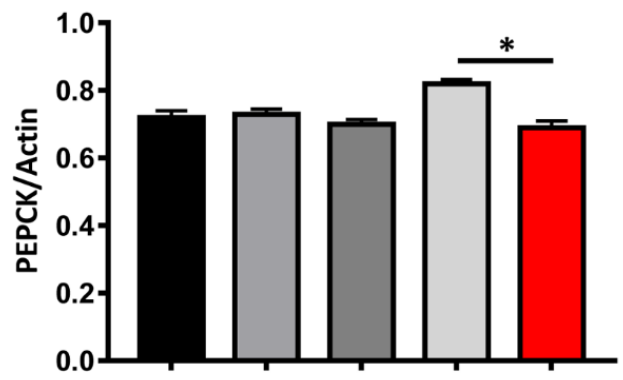

C

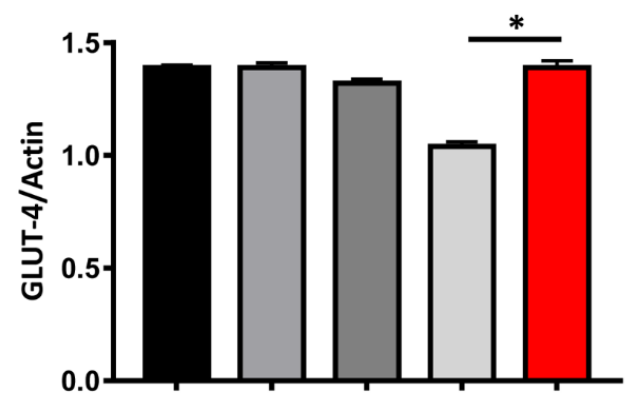

Figure 4. PEPCK expression in the liver and GLUT-4 expression in the skeletal muscle. The rats were randomly allocated to 5 treatments: (1) sham operation (Sham group), (2) sham with $750 \mathrm{mg} / \mathrm{kg} / \mathrm{d}$ GlcN intraperitoneally (ip) injected for 14 days (Sham + GlcN group), (3) ovariectomy (OVX group), (4) ovariectomy with $750 \mathrm{mg} / \mathrm{kg} / \mathrm{d}$ GlcN ip injected for 14 days (OVX+GlcN group), or (5) ovariectomy with $750 \mathrm{mg} / \mathrm{kg} / \mathrm{d}$ GlcN ip injected for 14 days with subcutaneous RLX at $0.5 \mathrm{mg} / \mathrm{kg} / \mathrm{d}$. ( $n=8$ in each group). (A) Increased PEPCK expression in the liver and decreased GLUT-4 expression in soleus muscle were only observed in OVX rats given GlcN. RLX treatment reversed these effects. (B) The OVX + GlcN group exhibited increased PEPCK expression. RLX significantly reduced PEPCK expression in OVX rats with GlcN treatment to nearly the same level as the Sham group. (C) The OVX + GlcN group demonstrated decreased GLUT-4 expression. RLX preserved the expression of GLUT-4 in OVX rats with GlcN, maintaining it at nearly the level of the Sham group. No significant difference was present in the PEPCK or GLUT-4 expression among the Sham + GlcN, OVX, Sham, and OVX + GlcN + RLX groups. ${ }^{*} p<0.05$.

\subsection{RXL Increased Extracellular Insulin Secretion and Cell Viability in MIN-6 Cells Treated with GlcN}

In order to clarify the roles of estrogen receptor $\alpha$ and estrogen receptor $\beta$ in the effects of RLX, the antagonists of estrogen receptor $\alpha$ and estrogen receptor $\beta$ were used. ICI 182,780 (antagonist to both estrogen receptor $\alpha$ and estrogen receptor $\beta$ ) and MPP (antagonist specific to estrogen receptor $\alpha$ ) were treated as indicated. Glucose increased extracellular insulin secretion, whereas GlcN reduced it. RLX reversed the GlcN-induced decrease in extracellular insulin secretion, whereas ICI 182,780 and MPP counteracted the effects of RLX on extracellular insulin secretion (Figure $5 \mathrm{~A}$ ). GlcN treatment reduced the optical density, as determined through the MTT assay, whereas RLX reversed this effect and increased optical density in the MIN-6 cells. Pretreatment with ICI 182,780 and MPP 
reduced the reversal effect of RLX, and the cell viability was similar to that after GlcN treatment (Figure 5B).
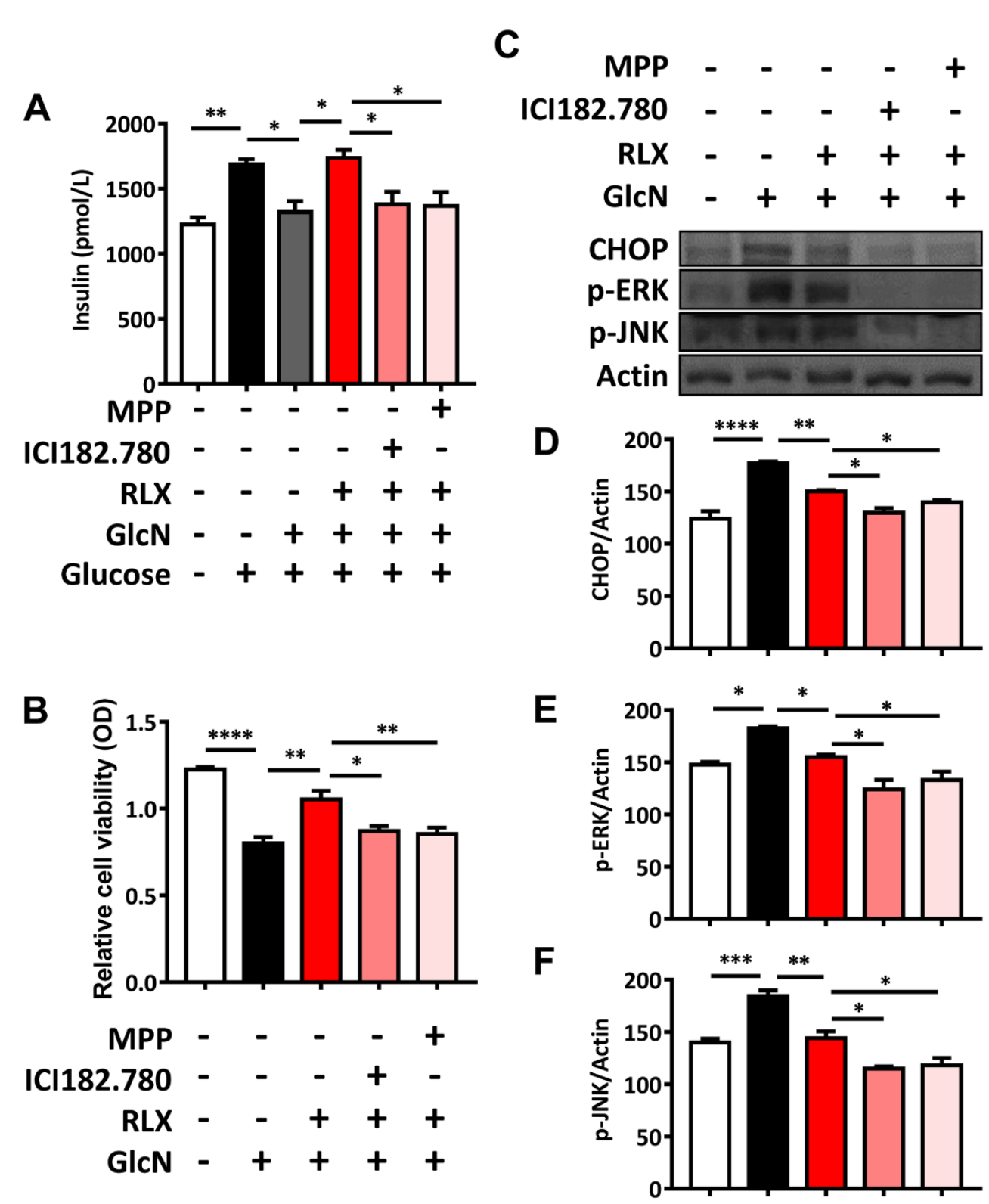

Figure 5. Extracellular insulin secretion, MTT assay, and Western blot analysis for the expression of ER stress-[associated proteins in MIN-6 cells. (A) Extracellular insulin secretion. Glucose increased extracellular insulin secretion, whereas GlcN reduced extracellular insulin secretion. RLX reversed GlcN-induced extracellular insulin secretion, whereas ICI 182,780 and MPP counteracted the effects of RLX. (B) MTT assay for cell viability. GlcN treatment reduced optical density in the MTT assay, whereas RLX counteracted this effect and even enhanced optical density. With combined ICI 182,780 and MMP treatment, the protective effect of RLX on cell viability was negated. (C) Western blot analysis for the expression of ER stress-associated proteins in MIN-6 cells: (D) CHOP, (E) p-ERK, and (F) p-JUK. GlcN treatment enhanced CHOP, p-ERK, and p-JNK expression, whereas RLX reversed these effects. Pretreatment with ICI 182,780 and MPP counteracted the reversal effect of RLX to protect against GlcN-induced CHOP, p-ERK, and p-JNK changes. Each bar represents the mean $\pm \mathrm{SEM}$. ${ }^{*} p$ $<0.05 ;{ }^{* *} p<0.01{ }^{* * *} p<0.001 ; * * * * 0.0001$. 
3.7. RXL Decreased the Expression of ER Stress-Associated Proteins CHOP, $p$-ERK, and $p$-JUN in MIN-6 Cells Treated with GlcN in Western Blot Analysis

GlcN treatment enhanced CHOP, p-ERK, and p-JNK expression, whereas RLX reversed these effects. Pretreatment with ICI 182,780 and MPP (estrogen receptor antagonists) counteracted the reversal effect of RLX to protect against GlcN-induced CHOP, p-ERK, and p-JNK increases (Figure 5C-F). These results indicate that GlcN induces ER stress, but RLX can relieve it. The effects of RLX are evident mainly through estrogen receptor $\alpha$.

\section{Discussion}

In previous studies, we have concluded that GlcN-induced IR in OVX rats was related to reduced insulin secretion, pancreatic $\beta$-cell apoptosis, and enlarged pancreatic islets, and that $E_{2}$ could counteract these adverse effects of in OVX rats [40,41]. In the present study, we further demonstrated that RLX, an SERM rather than an estrogen analog, can also ameliorate the deleterious effects of GlcN in OVX rats. Of the mechanisms underlying the protective effects of RLX which may be related to the combined effects of increasing GLUT-4 expression in skeletal muscle, decreasing PEPCK expression in the liver, inhibiting the growth of the pancreatic islets, and ameliorating ER stress in $\beta$-cells were shown to improve $\beta$-cell survival and function.

OP increases fracture risk and requires treatment to prevent subsequent comorbidities and mortality after fracture [19,22,25,26,49-76]. Knee OA leads to an increased risk of fall, which therefore increases fracture risk and required treatment [77-79]. OP and OA are common in older adults, especially in postmenopausal women, and they have negative impacts on quality of life $[25,62,80,81]$. OP is a clinically encountered comorbidity in older adults with OA $[59,62,82,83]$. Many patients (66\%) with end-stage OA have OP or osteopenia [84]. Simultaneous lower extremity varus malalignment and OP in postmenopausal women result in more rapid OA development [85]. Hand OA and low hand and arm bone mineral density are related and can increase the risk of wrist fracture [86]. Therefore, the combined use of RLX and GlcN clinically is likely because of the frequent comorbidity of OA and OP in postmenopausal women. RLX ameliorated OA in an OVX rat model, indicating that it is a potential candidate for treating postmenopausal women with OA and OP [87]. RLX improved plasma fasting blood glucose levels in OVX rats with DM induced by a high-fat diet and ip administered streptozotocin [88]. In a clinical trial, RLX elevated $2 \mathrm{~h}$ insulin levels and the insulin AUC during the oral glucose tolerance test (OGTT) through reduced hepatic extraction. The insulin-retaining effect of RLX may be helpful in postmenopausal women with decreased insulin reserves or those predisposed to T2DM [89]. Compared with a placebo group, RLX resulted in significantly lower HOMA-IR levels in postmenopausal women with IR in a double-blind randomized trial [90]. RLX may improve glucose levels in postmenopausal women taking GlcN.

$\mathrm{E}_{2}$ reduces hepatic gluconeogenesis-related genes including phosphoenolpyruvate carboxykinase 1 (Pck-1) and glucose 6-phosphatase (G6Pase). The effects of $E_{2}$ were inhibited in mice lacking liver estrogen receptor $\alpha$. Hepatic estrogen receptor signaling is related to gluconeogenesis maintenance in men [91]. In the current study, RLX reduced liver PEPCK expression in OVX rats treated with GlcN. The effects may, at least partially, be exerted through liver estrogen receptor $\alpha$.

Skeletal muscle estrogen receptor $\alpha$ plays a key protective role in the regulation of insulin action and metabolic homeostasis. Compared with estrogen receptor $\beta$ and GPR30, estrogen receptor $\alpha$ is expressed much more in both rodent and human muscle [92,93]. Total muscular GLUT-4 level determined the IR phenotype in estrogen receptor $\alpha$-knockout mice [94]. RLX can increase the mRNA expression of GLUT-4 in human skeletal muscle cells [95]. In the present study, RLX enhanced GLUT-4 expression in the soleus muscle. The effect of RLX on GLUT- 4 may be through estrogen receptor $\alpha$.

In a previous study, estrogen receptor $\alpha$ knockout reduced glucose-stimulated insulin secretion in a murine model. In addition, estrogen receptor $\alpha$ knockout in MIN- 6 cells enhanced ER stress and apoptosis, and overexpression of estrogen receptor $\alpha$ reduced 
oxidative stress-induced CHOP expression in MIN-6 cells. Thus, estrogen receptor $\alpha$ targets $\beta$-cell apoptosis susceptibility and insulin secretion capacity [96]. We have previously reported that GlcN impairs the insulin secretion of $\beta$-cells and enhances $\beta$-cell apoptosis through increases in ER stress-related proteins including CHOP, p-ERK, p-EIF2 $\alpha$, and pJNK in MIN-6 cells, whereas $E_{2}$ ameliorates the ER stress caused by GlcN [41]. In the current study, RLX, similarly to $E_{2}$, reversed these adverse effects of GlcN. RLX counteracted GlcNmediated reductions in extracellular insulin secretion, cell viability, and the expression of ER stress-associated proteins. Both ICI 182,780 and MMP inhibited these benefits of RLX, with no statistical differences in extracellular insulin secretion or cell viability, but differences in the expression of ER stress-associated proteins. Our results indicate that RLX ameliorates GlcN-induced dysfunction in pancreatic $\beta$-cells through estrogen receptors, mainly estrogen receptor $\alpha$ for cell viability and extracellular insulin secretion, and from increases in ER stress-associated proteins. Further studies are required to explore the mechanism of RLX in ER stress-associated protein suppression.

There was one limitation to our study: we did not stain Ki67 to clarify the roles of proliferation in pancreatic $\beta$-cells. Further studies may be required to clarify the roles of proliferation in pancreatic $\beta$-cells.

\section{Conclusions}

GlcN may lead to $\beta$-cell dysfunction and apoptosis via diminishing pancreatic $\beta$-cell viability and insulin secretion and increasing ER stress-associated protein levels. RLX can reverse the effects of GlcN, but pretreatment with ICI 182,780 and MPP can inhibit the reversal effects of RLX. The effects of RLX are exerted mainly through estrogen receptor $\alpha$. Uncovering more about the underlying mechanisms requires further study.

Author Contributions: Conceptualization, C.-H.C., H.-T.H., S.-Y.L. and L.K.; data curation, T.-L.C., C.-F.C. and S.-Y.L.; formal analysis, T.-L.C., M.-H.W. and L.K.; funding acquisition, C.-H.C. and L.K.; Investigation, C.-H.C., T.-L.C., H.-T.H. and L.K.; methodology, T.-L.C., C.-F.C. and S.-Y.L.; project administration, C.-H.C. and L.K.; Software, T.-L.C., H.-T.H., C.-F.C. and M.-H.W.; supervision, L.K. and C.-H.C.; validation, H.-T.H., S.-Y.L. and L.K.; writing-original draft, C.-H.C. and T.-L.C.; writing-review and editing, C.-F.C., S.-Y.L., M.-H.W. and L.K. All authors have read and agreed to the published version of the manuscript.

Funding: This study was supported in part by the National Health Research Institute (NHRI-EX1019935EI) of Taiwan, National Cheng Kung University (NCKUH- 10406014), Kaohsiung Municipal Ta-Tung Hospital (KMTTH-109-R014 and KMTTH-DK(B) 110002-1), Kaohsiung Medical University (NPUST KMU-109-P002, NCTUKMU108-BIO-04, KMU-TC108A02-1, KMU-DK(A)110003 and KMUDK(B) 110002) and the Minister of Science and Technology, Taiwan (MOST 104-2314-B-006-071-MY2, 108-2314-B-037-059-MY3 and 110-2314-B-037-029-MY3) of Taiwan. The funders had no role in the study design, data collection, and analysis; decision to publish; or preparation of the manuscript.

Institutional Review Board Statement: Not applicable.

Informed Consent Statement: Not applicable.

Data Availability Statement: Data are available on request.

Acknowledgments: We are grateful to W.T. Chang and Y.S. Lin for their assistance in this study. This manuscript was edited by Wallace Academic Editing.

Conflicts of Interest: The authors declare no conflict of interest.

\section{References}

1. Jiajue, R.; Qi, X.; Jiang, Y.; Wang, Q.; Wang, W.; Pei, Y.; Wang, X.; Huang, W.; Zheng, X.; Ning, Z.; et al. Incident Fracture Risk in Type 2 Diabetic Postmenopausal Women in Mainland China: Peking Vertebral Fracture Study. Calcif. Tissue Int. 2019, 105, 466-475. [CrossRef]

2. Cross, M.; Smith, E.; Hoy, D.; Nolte, S.; Ackerman, I.; Fransen, M.; Bridgett, L.; Williams, S.; Guillemin, F.; Hill, C.L.; et al. The global burden of hip and knee osteoarthritis: Estimates from the global burden of disease 2010 study. Ann. Rheum. Dis. 2014, 73, 1323-1330. [CrossRef] 
3. Veronese, N.; Cooper, C.; Reginster, J.Y.; Hochberg, M.; Branco, J.; Bruyère, O.; Chapurlat, R.; Al-Daghri, N.; Dennison, E.; Herrero-Beaumont, G.; et al. Type 2 diabetes mellitus and osteoarthritis. Semin. Arthritis Rheum. 2019, 49, 9-19. [CrossRef] [PubMed]

4. Hsu, C.H.; Hsu, N.C.; Shih, C.L.; Huang, H.T.; Chen, C.H.; Chou, P.H. Medication-Taking Habit and Outcome of Glucosamine Sulfate for Osteoarthritis Patients Influenced by National Health Insurance Regulations in Taiwan. J. Clin. Med. 2019, 8, 1734. [CrossRef]

5. Ghouri, A.; Conaghan, P.G. Prospects for Therapies in Osteoarthritis. Calcif. Tissue Int. 2020, 1-12. [CrossRef] [PubMed]

6. Guo, Q.; Hu, H.; Zhou, Y.; Yan, Y.; Wei, X.; Fan, X.; Yang, D.; He, H.; Oh, Y.; Chen, K.; et al. Glucosamine induces increased musclin gene expression through endoplasmic reticulum stress-induced unfolding protein response signaling pathways in mouse skeletal muscle cells. Food Chem. Toxicol. 2019, 125, 95-105. [CrossRef]

7. Ciaraldi, T.P.; Carter, L.; Nikoulina, S.; Mudaliar, S.; McClain, D.A.; Henry, R.R. Glucosamine regulation of glucose metabolism in cultured human skeletal muscle cells: Divergent effects on glucose transport/phosphorylation and glycogen synthase in non-diabetic and type 2 diabetic subjects. Endocrinology 1999, 140, 3971-3980. [CrossRef] [PubMed]

8. D'Alessandris, C.; Andreozzi, F.; Federici, M.; Cardellini, M.; Brunetti, A.; Ranalli, M.; Del Guerra, S.; Lauro, D.; Del Prato, S.; Marchetti, P.; et al. Increased O-glycosylation of insulin signaling proteins results in their impaired activation and enhanced susceptibility to apoptosis in pancreatic beta-cells. FASEB J. 2004, 18, 959-961. [CrossRef] [PubMed]

9. Biggee, B.A.; Blinn, C.M.; Nuite, M.; Silbert, J.E.; McAlindon, T.E. Effects of oral glucosamine sulphate on serum glucose and insulin during an oral glucose tolerance test of subjects with osteoarthritis. Ann. Rheum. Dis. 2007, 66, 260-262. [CrossRef]

10. Monauni, T.; Zenti, M.G.; Cretti, A.; Daniels, M.C.; Targher, G.; Caruso, B.; Caputo, M.; McClain, D.; Del Prato, S.; Giaccari, A.; et al. Effects of glucosamine infusion on insulin secretion and insulin action in humans. Diabetes 2000, 49, 926-935. [CrossRef]

11. Muniyappa, R.; Karne, R.J.; Hall, G.; Crandon, S.K.; Bronstein, J.A.; Ver, M.R.; Hortin, G.L.; Quon, M.J. Oral glucosamine for 6 weeks at standard doses does not cause or worsen insulin resistance or endothelial dysfunction in lean or obese subjects. Diabetes 2006, 55, 3142-3150. [CrossRef] [PubMed]

12. Scroggie, D.A.; Albright, A.; Harris, M.D. The effect of glucosamine-chondroitin supplementation on glycosylated hemoglobin levels in patients with type 2 diabetes mellitus: A placebo-controlled, double-blinded, randomized clinical trial. Arch. Intern. Med. 2003, 163, 1587-1590. [CrossRef]

13. Mauvais-Jarvis, F.; Clegg, D.J.; Hevener, A.L. The role of estrogens in control of energy balance and glucose homeostasis. Endocr. Rev. 2013, 34, 309-338. [CrossRef] [PubMed]

14. Le May, C.; Chu, K.; Hu, M.; Ortega, C.S.; Simpson, E.R.; Korach, K.S.; Tsai, M.J.; Mauvais-Jarvis, F. Estrogens protect pancreatic beta-cells from apoptosis and prevent insulin-deficient diabetes mellitus in mice. Proc. Natl. Acad. Sci. USA 2006, 103, 9232-9237. [CrossRef] [PubMed]

15. Riant, E.; Waget, A.; Cogo, H.; Arnal, J.F.; Burcelin, R.; Gourdy, P. Estrogens protect against high-fat diet-induced insulin resistance and glucose intolerance in mice. Endocrinology 2009, 150, 2109-2117. [CrossRef]

16. Tiano, J.P.; Delghingaro-Augusto, V.; Le May, C.; Liu, S.; Kaw, M.K.; Khuder, S.S.; Latour, M.G.; Bhatt, S.A.; Korach, K.S.; Najjar, S.M.; et al. Estrogen receptor activation reduces lipid synthesis in pancreatic islets and prevents beta cell failure in rodent models of type 2 diabetes. J. Clin. Investig. 2011, 121, 3331-3342. [CrossRef]

17. Liu, S.; Le May, C.; Wong, W.P.; Ward, R.D.; Clegg, D.J.; Marcelli, M.; Korach, K.S.; Mauvais-Jarvis, F. Importance of extranuclear estrogen receptor-alpha and membrane $G$ protein-coupled estrogen receptor in pancreatic islet survival. Diabetes 2009, 58, 2292-2302. [CrossRef]

18. Rodriguez, C.; Patel, A.V.; Calle, E.E.; Jacob, E.J.; Thun, M.J. Estrogen replacement therapy and ovarian cancer mortality in a large prospective study of US women. JAMA 2001, 285, 1460-1465. [CrossRef]

19. Conley, R.B.; Adib, G.; Adler, R.A.; Akesson, K.E.; Alexander, I.M.; Amenta, K.C.; Blank, R.D.; Brox, W.T.; Carmody, E.E.; Chapman-Novakofski, K.; et al. Secondary Fracture Prevention: Consensus Clinical Recommendations from a Multistakeholder Coalition. J. Bone Miner. Res. 2020, 35, 36-52. [CrossRef]

20. Tatangelo, G.; Watts, J.; Lim, K.; Connaughton, C.; Abimanyi-Ochom, J.; Borgstrom, F.; Nicholson, G.C.; Shore-Lorenti, C.; Stuart, A.L.; Iuliano-Burns, S.; et al. The Cost of Osteoporosis, Osteopenia, and Associated Fractures in Australia in 2017. J. Bone Miner. Res. 2019, 34, 616-625. [CrossRef]

21. Shieh, A.; Greendale, G.A.; Cauley, J.A.; Karvonen-Gutierrez, C.; Crandall, C.J.; Karlamangla, A.S. Estradiol and FollicleStimulating Hormone as Predictors of Onset of Menopause Transition-Related Bone Loss in Pre- and Perimenopausal Women. J. Bone Miner. Res. 2019, 34, 2246-2253. [CrossRef] [PubMed]

22. Lewiecki, E.M.; Binkley, N.; Bilezikian, J.P. Treated Osteoporosis Is Still Osteoporosis. J. Bone Miner. Res. 2019, 34, 605-606. [CrossRef]

23. Crandall, C.J.; Larson, J.; Manson, J.E.; Cauley, J.A.; LaCroix, A.Z.; Wactawski-Wende, J.; Datta, M.; Sattari, M.; Schousboe, J.T.; Leslie, W.D.; et al. A Comparison of US and Canadian Osteoporosis Screening and Treatment Strategies in Postmenopausal Women. J. Bone Miner. Res. 2019, 34, 607-615. [CrossRef]

24. Chang, P.Y.; Feldman, D.; Stefanick, M.L.; McDonnell, D.P.; Thompson, B.M.; McDonald, J.G.; Lee, J.S. 27-Hydroxycholesterol, an Endogenous SERM, and Risk of Fracture in Postmenopausal Women: A Nested Case-Cohort Study in the Women's Health Initiative. J. Bone Miner. Res. 2019, 34, 59-66. [CrossRef] 
25. Wu, C.H.; Hung, W.C.; Chang, I.L.; Tsai, T.T.; Chang, Y.F.; McCloskey, E.V.; Watts, N.B.; McClung, M.R.; Huang, C.F.; Chen, C.H.; et al. Pharmacologic intervention for prevention of fractures in osteopenic and osteoporotic postmenopausal women: Systemic review and meta-analysis. Bone Rep. 2020, 13, 100729. [CrossRef]

26. Wu, C.H.; Chang, Y.F.; Chen, C.H.; Lewiecki, E.M.; Wuster, C.; Reid, I.; Tsai, K.S.; Matsumoto, T.; Mercado-Asis, L.B.; Chan, D.C.; et al. Consensus Statement on the Use of Bone Turnover Markers for Short-Term Monitoring of Osteoporosis Treatment in the Asia-Pacific Region. J. Clin. Densitom. 2021, 24, 3-13. [CrossRef] [PubMed]

27. Centofanti, F.; Santoro, M.; Marini, M.; Visconti, V.V.; Rinaldi, A.M.; Celi, M.; D'Arcangelo, G.; Novelli, G.; Orlandi, A.; Tancredi, V.; et al. Identification of Aberrantly-Expressed Long Non-Coding RNAs in Osteoblastic Cells from Osteoporotic Patients. Biomedicines 2020, 8, 65. [CrossRef]

28. Taylor, E.A.; Donnelly, E.; Yao, X.; Johnson, M.L.; Amugongo, S.K.; Kimmel, D.B.; Lane, N.E. Sequential Treatment of Estrogen Deficient, Osteopenic Rats with Alendronate, Parathyroid Hormone (1-34), or Raloxifene Alters Cortical Bone Mineral and Matrix Composition. Calcif. Tissue Int. 2020, 106, 303-314. [CrossRef]

29. Hozumi, Y.; Kawano, M.; Jordan, V.C. In vitro study of the effect of raloxifene on lipid metabolism compared with tamoxifen. Eur. J. Endocrinol. 2000, 143, 427-430. [CrossRef]

30. Tiano, J.; Mauvais-Jarvis, F. Selective estrogen receptor modulation in pancreatic beta-cells and the prevention of type 2 diabetes. Islets 2012, 4, 173-176. [CrossRef] [PubMed]

31. Bernales, S.; Papa, F.R.; Walter, P. Intracellular signaling by the unfolded protein response. Annu. Rev. Cell Dev. Biol. 2006, 22, 487-508. [CrossRef] [PubMed]

32. Chiu, C.F.; Lai, G.Y.; Chen, C.H.; Chiu, C.C.; Hung, S.W.; Chang, C.F. 6,7-Dihydroxy-2-(4'-hydroxyphenyl)naphthalene induces HCT116 cell apoptosis through activation of endoplasmic reticulum stress and the extrinsic apoptotic pathway. Drug Des. Dev. Ther. 2019, 13, 1609-1621. [CrossRef]

33. Gundamaraju, R.; Lu, W.; Azimi, I.; Eri, R.; Sohal, S.S. Endogenous Anti-Cancer Candidates in GPCR, ER Stress, and EMT. Biomedicines 2020, 8, 402. [CrossRef] [PubMed]

34. Osman, A.; Benameur, T.; Korashy, H.M.; Zeidan, A.; Agouni, A. Interplay between Endoplasmic Reticulum Stress and Large Extracellular Vesicles (Microparticles) in Endothelial Cell Dysfunction. Biomedicines 2020, 8, 409. [CrossRef] [PubMed]

35. Marchetti, P.; Bugliani, M.; Lupi, R.; Marselli, L.; Masini, M.; Boggi, U.; Filipponi, F.; Weir, G.C.; Eizirik, D.L.; Cnop, M. The endoplasmic reticulum in pancreatic beta cells of type 2 diabetes patients. Diabetologia 2007, 50, 2486-2494. [CrossRef] [PubMed]

36. Laybutt, D.R.; Preston, A.M.; Akerfeldt, M.C.; Kench, J.G.; Busch, A.K.; Biankin, A.V.; Biden, T.J. Endoplasmic reticulum stress contributes to beta cell apoptosis in type 2 diabetes. Diabetologia 2007, 50, 752-763. [CrossRef] [PubMed]

37. Galli, A.; Marciani, P.; Marku, A.; Ghislanzoni, S.; Bertuzzi, F.; Rossi, R.; Di Giancamillo, A.; Castagna, M.; Perego, C. Verbascoside Protects Pancreatic beta-Cells against ER-Stress. Biomedicines 2020, 8, 582. [CrossRef] [PubMed]

38. Hwang, M.S.; Baek, W.K. Glucosamine induces autophagic cell death through the stimulation of ER stress in human glioma cancer cells. Biochem. Biophys. Res. Commun. 2010, 399, 111-116. [CrossRef]

39. Morin, M.J.; Porter, C.W.; McKernan, P.; Bernacki, R.J. The biochemical and ultrastructural effects of tunicamycin and Dglucosamine in L1210 leukemic cells. J. Cell Physiol. 1983, 114, 162-172. [CrossRef]

40. Kang, L.; Chen, C.H.; Cheng, Y.C.; Chang, C.H.; Lee, C.T.; Chang, J.K.; Cheng, J.T.; Chang, F.M. Glucosamine-induced insulin resistance in ovariectomized rats is relevant to decreasing the expression of glucose transport protein subtype 4 in the skeletal muscle and in increasing the size of pancreatic islets. Menopause 2012, 19, 496-502. [CrossRef]

41. Kang, L.; Chen, C.H.; Wu, M.H.; Chang, J.K.; Chang, F.M.; Cheng, J.T. 17beta-estradiol protects against glucosamine-induced pancreatic beta-cell dysfunction. Menopause 2014, 21, 1239-1248. [CrossRef] [PubMed]

42. Ho, M.L.; Chen, Y.H.; Liao, H.J.; Chen, C.H.; Hung, S.H.; Lee, M.J.; Fu, Y.C.; Wang, Y.H.; Wang, G.J.; Chang, J.K. Simvastatin increases osteoblasts and osteogenic proteins in ovariectomized rats. Eur. J. Clin. Investig. 2009, 39, 296-303. [CrossRef]

43. Juan, Y.S.; Chuang, S.M.; Long, C.Y.; Chen, C.H.; Levin, R.M.; Liu, K.M.; Huang, C.H. Neuroprotection of green tea catechins on surgical menopause-induced overactive bladder in a rat model. Menopause 2012, 19, 346-354. [CrossRef] [PubMed]

44. Chen, C.H.; Kang, L.; Lin, R.W.; Fu, Y.C.; Lin, Y.S.; Chang, J.K.; Chen, H.T.; Chen, C.H.; Lin, S.Y.; Wang, G.J.; et al. (-)Epigallocatechin-3-gallate improves bone microarchitecture in ovariectomized rats. Menopause 2013, 20, 687-694. [CrossRef]

45. Chen, C.H.; Huang, T.H.; Cheng, T.L.; Chang, C.F.; Wang, C.Z.; Wu, M.H.; Kang, L. Exercise training ameliorates glucosamineinduced insulin resistance in ovariectomized rats. Menopause 2017, 24, 617-623. [CrossRef]

46. Chen, C.H.; Ho, M.L.; Chang, L.H.; Kang, L.; Lin, Y.S.; Lin, S.Y.; Wu, S.C.; Chang, J.K. Parathyroid hormone-(1-34) ameliorated knee osteoarthritis in rats via autophagy. J. Appl. Physiol. 2018, 124, 1177-1185. [CrossRef] [PubMed]

47. Chou, H.C.; Chen, C.H.; Chou, L.Y.; Cheng, T.L.; Kang, L.; Chuang, S.C.; Lin, Y.S.; Ho, M.L.; Wang, Y.H.; Lin, S.Y.; et al. Discoidin Domain Receptors 1 Inhibition Alleviates Osteoarthritis via Enhancing Autophagy. Int. J. Mol. Sci. 2020, 21, 6991. [CrossRef] [PubMed]

48. Chen, C.H.; Kang, L.; Chang, L.H.; Cheng, T.L.; Lin, S.Y.; Wu, S.C.; Lin, Y.S.; Chuang, S.C.; Lee, T.C.; Chang, J.K.; et al. Intraarticular low-dose parathyroid hormone (1-34) improves mobility and articular cartilage quality in a preclinical age-related knee osteoarthritis model. Bone Jt. Res. 2021, 10, 514-525. [CrossRef] [PubMed]

49. Lee, T.C.; Lee, Y.L.; Chen, J.C.; Chen, C.H.; Ho, P.S. Impact of type 2 diabetes on postoperative outcome after hip fracture: Nationwide population-based study in Taiwan. BMJ Open Diabetes Res. Care 2020, 8, e000843. [CrossRef] [PubMed] 
50. Chen, C.H.; Huang, P.J.; Huang, H.T.; Lin, S.Y.; Wang, H.Y.; Fang, T.J.; Lin, Y.C.; Ho, C.J.; Lee, T.C.; Lu, Y.M.; et al. Impact of orthogeriatric care, comorbidity, and complication on 1-year mortality in surgical hip fracture patients: An observational study. Medicine 2019, 98, e17912. [CrossRef] [PubMed]

51. Chen, C.L.; Chen, C.M.; Wang, C.Y.; Ko, P.W.; Chen, C.H.; Hsieh, C.P.; Chiu, H.C. Frailty is Associated with an Increased Risk of Major Adverse Outcomes in Elderly Patients Following Surgical Treatment of Hip Fracture. Sci. Rep. 2019, 9, 19135. [CrossRef] [PubMed]

52. Chen, C.H.; Elsalmawy, A.H.; Ish-Shalom, S.; Lim, S.J.; Al-Ali, N.S.; Cunha-Borges, J.L.; Yang, H.; Casas, N.; Altan, L.; Moll, T.; et al. Study description and baseline characteristics of the population enrolled in a multinational, observational study of teriparatide in postmenopausal women with osteoporosis: The Asia and Latin America Fracture Observational Study (ALAFOS). Curr. Med. Res. Opin. 2019, 35, 1041-1049. [CrossRef] [PubMed]

53. Borhan, S.; Papaioannou, A.; Gajic-Veljanoski, O.; Kennedy, C.; Ioannidis, G.; Berger, C.; Goltzman, D.; Josse, R.; Kovacs, C.S.; Hanley, D.A.; et al. Incident Fragility Fractures Have a Long-Term Negative Impact on Health-Related Quality of Life of Older People: The Canadian Multicentre Osteoporosis Study. J. Bone Miner. Res. 2019, 34, 838-848. [CrossRef] [PubMed]

54. Bliuc, D.; Tran, T.; van Geel, T.; Adachi, J.D.; Berger, C.; van den Bergh, J.; Eisman, J.A.; Geusens, P.; Goltzman, D.; Hanley, D.A.; et al. Reduced Bone Loss Is Associated With Reduced Mortality Risk in Subjects Exposed to Nitrogen Bisphosphonates: A Mediation Analysis. J. Bone Miner. Res. 2019, 34, 2001-2011. [CrossRef] [PubMed]

55. Anastasilakis, A.D.; Papapoulos, S.E.; Polyzos, S.A.; Appelman-Dijkstra, N.M.; Makras, P. Zoledronate for the Prevention of Bone Loss in Women Discontinuing Denosumab Treatment. A Prospective 2-Year Clinical Trial. J. Bone Miner. Res. 2019, 34, $2220-2228$. [CrossRef] [PubMed]

56. Osagie-Clouard, L.; Sanghani-Kerai, A.; Coathup, M.; Meeson, R.; Briggs, T.; Blunn, G. The influence of parathyroid hormone 1-34 on the osteogenic characteristics of adipose- and bone-marrow-derived mesenchymal stem cells from juvenile and ovarectomized rats. Bone Jt. Res. 2019, 8, 397-404. [CrossRef] [PubMed]

57. Wu, Y.Z.; Huang, H.T.; Cheng, T.L.; Lu, Y.M.; Lin, S.Y.; Ho, C.J.; Lee, T.C.; Hsu, C.H.; Huang, P.J.; Huang, H.H.; et al. Application of microrna in human osteoporosis and fragility fracture: A systemic review of literatures. Int. J. Mol. Sci. 2021, $22,5232$. [CrossRef] [PubMed]

58. Saad, R.K.; Harb, H.; Bou-Orm, I.R.; Ammar, W.; El-Hajj Fuleihan, G. Secular Trends of Hip Fractures in Lebanon, 2006 to 2017: Implications for Clinical Practice and Public Health Policy in the Middle East Region. J. Bone Miner. Res. 2020, 35, 71-80. [CrossRef]

59. Li, S.; Mao, Y.; Zhou, F.; Yang, H.; Shi, Q.; Meng, B. Gut microbiome and osteoporosis: A review. Bone Jt. Res. 2020, 9, 524-530. [CrossRef]

60. Huang, H.T.; Cheng, T.L.; Lin, S.Y.; Ho, C.J.; Chyu, J.Y.; Yang, R.S.; Chen, C.H.; Shen, C.L. Osteoprotective Roles of Green Tea Catechins. Antioxidants 2020, 9, 1136. [CrossRef]

61. Chou, Y.S.; Jiang, H.J.; Chen, C.H.; Ho, P.S.; Lee, T.C. Proton pump inhibitor use and risk of hip fracture in patients with type 2 diabetes. Sci. Rep. 2020, 10, 1-8. [CrossRef] [PubMed]

62. Dahl, C.; Holvik, K.; Meyer, H.E.; Stigum, H.; Solbakken, S.M.; Schei, B.; Sogaard, A.J.; Omsland, T.K. Increased Mortality in Hip Fracture Patients Living Alone: A NOREPOS Study. J. Bone Miner. Res. 2021, 36, 480-488. [CrossRef]

63. Chen, C.H.; Lim, S.J.; Oh, J.K.; Huang, T.W.; Zeng, Y.H.; Wu, M.T.; Yang, H.L.; Cheung, J.P.; Kim, J.W.; Han, J.H.; et al. Teriparatide in East Asian Postmenopausal Women with Osteoporosis in a Real-World Setting: A Baseline Analysis of the Asia and Latin America Fracture Observational Study (ALAFOS). Clin. Interv. Aging 2020, 15, 111-121. [CrossRef]

64. Lin, S.Y.; Huang, H.T.; Chou, S.H.; Ho, C.J.; Liu, Z.M.; Chen, C.H.; Lu, C.C. The Safety of Continuing Antiplatelet Medication Among Elderly Patients Undergoing Urgent Hip Fracture Surgery. Orthopedics 2019, 42, 268-274. [CrossRef] [PubMed]

65. Chan, D.D.; Chang, L.Y.; Akesson, K.E.; Mitchell, P.; Chen, C.H.; Lewiecki, E.M.; Lee, J.K.; Lau, T.C.; Songpatanasilp, T.; Lee, K.B.; et al. Consensus on best practice standards for Fracture Liaison Service in the Asia-Pacific region. Arch. Osteoporos. 2018, 13, 1-6. [CrossRef] [PubMed]

66. Chang, L.Y.; Tsai, K.S.; Peng, J.K.; Chen, C.H.; Lin, G.T.; Lin, C.H.; Tu, S.T.; Mao, I.C.; Gau, Y.L.; Liu, H.C.; et al. The development of Taiwan Fracture Liaison Service network. Osteoporos. Sarcopenia 2018, 4, 47-52. [CrossRef]

67. Chen, C.H.; Elsalmawy, A.H.; Ish-Shalom, S.; Lim, S.J.; AlAli, N.S.; Cunha-Borges, J.L.; Yang, H.; Casas, N.; Altan, L.; Belaya, Z.; et al. The Effect of Teriparatide Treatment on the Risk of Fragility Fractures in Postmenopausal Women with Osteoporosis: Results from the Asian and Latin America Fracture Observational Study (ALAFOS). Calcif. Tissue Int. 2021, in press. [CrossRef]

68. Lisk, R.; Yeong, K.; Fluck, D.; Fry, C.H.; Han, T.S. The Ability of the Nottingham Hip Fracture Score to Predict Mobility, Length of Stay and Mortality in Hospital, and Discharge Destination in Patients Admitted with a Hip Fracture. Calcif. Tissue Int. 2020, 107, 319-326. [CrossRef]

69. Mortensen, S.J.; Mohamadi, A.; Wright, C.L.; Chan, J.J.; Weaver, M.J.; von Keudell, A.; Nazarian, A. Medications as a Risk Factor for Fragility Hip Fractures: A Systematic Review and Meta-analysis. Calcif. Tissue Int. 2020, 107, 1-9. [CrossRef]

70. Tei, R.M.H.; Ramlau-Hansen, C.H.; Plana-Ripoll, O.; Brink, O.; Langdahl, B.L. OFELIA: Prevalence of Osteoporosis in Fragility Fracture Patients. Calcif. Tissue Int. 2019, 104, 102-114. [CrossRef] [PubMed]

71. Silverman, S.; Langdahl, B.L.; Fujiwara, S.; Saag, K.; Napoli, N.; Soen, S.; Enomoto, H.; Melby, T.E.; Disch, D.P.; Marin, F.; et al Reduction of Hip and Other Fractures in Patients Receiving Teriparatide in Real-World Clinical Practice: Integrated Analysis of Four Prospective Observational Studies. Calcif. Tissue Int. 2019, 104, 193-200. [CrossRef] [PubMed] 
72. Chen, L.R.; Ko, N.Y.; Chen, K.H. Medical Treatment for Osteoporosis: From Molecular to Clinical Opinions. Int. J. Mol. Sci. 2019, 20, 2213. [CrossRef]

73. Macias, I.; Alcorta-Sevillano, N.; Rodriguez, C.I.; Infante, A. Osteoporosis and the Potential of Cell-Based Therapeutic Strategies. Int. J. Mol. Sci. 2020, 21, 1653. [CrossRef] [PubMed]

74. Ukon, Y.; Makino, T.; Kodama, J.; Tsukazaki, H.; Tateiwa, D.; Yoshikawa, H.; Kaito, T. Molecular-Based Treatment Strategies for Osteoporosis: A Literature Review. Int. J. Mol. Sci. 2019, 20, 2557. [CrossRef]

75. Hsu, C.Y.; Chen, L.R.; Chen, K.H. Osteoporosis in Patients with Chronic Kidney Diseases: A Systemic Review. Int. J. Mol. Sci. 2020, 21, 6864. [CrossRef] [PubMed]

76. Chandra, A.; Rajawat, J. Skeletal Aging and Osteoporosis: Mechanisms and Therapeutics. Int. J. Mol. Sci. 2021, $22,3553$. [CrossRef]

77. Wang, J.; Zhou, L.; Zhang, Y.; Huang, L.; Shi, Q. Mesenchymal stem cells-A promising strategy for treating knee osteoarthritis. Bone Jt. Res. 2020, 9, 719-728. [CrossRef]

78. Luk, H.Y.; Appell, C.; Chyu, M.C.; Chen, C.H.; Wang, C.Y.; Yang, R.S.; Shen, C.L. Impacts of Green Tea on Joint and Skeletal Muscle Health: Prospects of Translational Nutrition. Antioxidants 2020, 9, 1050. [CrossRef] [PubMed]

79. Hain, B.A.; Jude, B.; Xu, H.; Smuin, D.M.; Fox, E.J.; Elfar, J.C.; Waning, D.L. Zoledronic Acid Improves Muscle Function in Healthy Mice Treated with Chemotherapy. J. Bone Miner. Res. 2020, 35, 368-381. [CrossRef]

80. Chakhtoura, M.; Dagher, H.; Sharara, S.; Ajjour, S.; Chamoun, N.; Cauley, J.; Mahfoud, Z.; Boudreau, R.; El Hajj Fuleihan, G. Systematic review of major osteoporotic fracture to hip fracture incidence rate ratios worldwide: Implications for Fracture Risk Assessment Tool (FRAX)-derived estimates. J. Bone Miner. Res. 2021. [CrossRef]

81. Pickering, M.E.; Chapurlat, R. Where Two Common Conditions of Aging Meet: Osteoarthritis and Sarcopenia. Calcif. Tissue Int. 2020, 107, 203-211. [CrossRef] [PubMed]

82. Chu, L.; Liu, X.; He, Z.; Han, X.; Yan, M.; Qu, X.; Li, X.; Yu, Z. Articular Cartilage Degradation and Aberrant Subchondral Bone Remodeling in Patients with Osteoarthritis and Osteoporosis. J. Bone Miner. Res. 2020, 35, 505-515. [CrossRef] [PubMed]

83. Shao, L.T.; Gou, Y.; Fang, J.K.; Hu, Y.P.; Lian, Q.Q.; Zhang, Y.Y.; Wang, Y.D.; Tian, F.M.; Zhang, L. Parathyroid hormone (1-34) ameliorates cartilage degeneration and subchondral bone deterioration in collagenase-induced osteoarthritis model in mice. Bone Jt. Res. 2020, 9, 675-688. [CrossRef]

84. Lingard, E.A.; Mitchell, S.Y.; Francis, R.M.; Rawlings, D.; Peaston, R.; Birrell, F.N.; McCaskie, A.W. The prevalence of osteoporosis in patients with severe hip and knee osteoarthritis awaiting joint arthroplasty. Age Ageing 2010, 39, 234-239. [CrossRef]

85. Wang, S.P.; Wu, P.K.; Lee, C.H.; Shih, C.M.; Chiu, Y.C.; Hsu, C.E. Association of osteoporosis and varus inclination of the tibial plateau in postmenopausal women with advanced osteoarthritis of the knee. BMC Musculoskelet. Disord. 2021, 22, 1-8. [CrossRef]

86. Kasher, M.; Williams, F.M.K.; Freidin, M.B.; Cherny, S.; Livshits, G. An in-depth study of the associations between osteoarthritisand osteoporosis-related phenotypes at different skeletal locations. Osteoporos. Int. 2020, 31, 2197-2208. [CrossRef]

87. Bei, M.J.; Tian, F.M.; Xiao, Y.P.; Cao, X.H.; Liu, N.; Zheng, Z.Y.; Dai, M.W.; Wang, W.Y.; Song, H.P.; Zhang, L. Raloxifene retards cartilage degradation and improves subchondral bone micro-architecture in ovariectomized rats with patella baja-inducedpatellofemoral joint osteoarthritis. Osteoarthr. Cartil. 2020, 28, 344-355. [CrossRef] [PubMed]

88. Ebrahimi, M.N.; Khaksari, M.; Sepehri, G.; Karam, G.A.; Raji-Amirhasani, A.; Azizian, H. The effects of alone and combination tamoxifen, raloxifene and estrogen on lipid profile and atherogenic index of ovariectomized type 2 diabetic rats. Life Sci. 2020, 263, 118573. [CrossRef]

89. Nagamani, M.; Szymajda, A.; Sepilian, V.; Urban, R.J.; Gilkison, C. Effects of raloxifene on insulin sensitivity, beta-cell function, and hepatic insulin extraction in normal postmenopausal women. Fertil. Steril. 2008, 89, 614-619. [CrossRef] [PubMed]

90. Grover-Paez, F.; Zavalza-Gomez, A.B.; Anaya-Prado, R. Raloxifene modifies the insulin sensitivity and lipid profile of postmenopausal insulin resistant women. Gynecol. Endocrinol. 2013, 29, 674-677. [CrossRef]

91. Qiu, S.; Vazquez, J.T.; Boulger, E.; Liu, H.; Xue, P.; Hussain, M.A.; Wolfe, A. Hepatic estrogen receptor $\alpha$ is critical for regulation of gluconeogenesis and lipid metabolism in males. Sci. Rep. 2017, 7, 1-12. [CrossRef] [PubMed]

92. Hevener, A.L.; Ribas, V.; Moore, T.M.; Zhou, Z. The Impact of Skeletal Muscle ER $\alpha$ on Mitochondrial Function and Metabolic Health. Endocrinology 2020, 161, bqz017. [CrossRef] [PubMed]

93. Ribas, V.; Drew, B.G.; Zhou, Z.; Phun, J.; Kalajian, N.Y.; Soleymani, T.; Daraei, P.; Widjaja, K.; Wanagat, J.; de Aguiar Vallim, T.Q.; et al. Skeletal muscle action of estrogen receptor alpha is critical for the maintenance of mitochondrial function and metabolic homeostasis in females. Sci. Transl. Med. 2016, 8, 334ra54. [CrossRef] [PubMed]

94. Bryzgalova, G.; Gao, H.; Ahren, B.; Zierath, J.R.; Galuska, D.; Steiler, T.L.; Dahlman-Wright, K.; Nilsson, S.; Gustafsson, J.A.; Efendic, S.; et al. Evidence that oestrogen receptor-alpha plays an important role in the regulation of glucose homeostasis in mice: Insulin sensitivity in the liver. Diabetologia 2006, 49, 588-597. [CrossRef] [PubMed]

95. Dieli-Conwright, C.M.; Spektor, T.M.; Rice, J.C.; Todd Schroeder, E. Oestradiol and SERM treatments influence oestrogen receptor coregulator gene expression in human skeletal muscle cells. Acta Physiol. 2009, 197, 187-196. [CrossRef]

96. Zhou, Z.; Ribas, V.; Rajbhandari, P.; Drew, B.G.; Moore, T.M.; Fluitt, A.H.; Reddish, B.R.; Whitney, K.A.; Georgia, S.; Vergnes, L.; et al. Estrogen receptor alpha protects pancreatic beta-cells from apoptosis by preserving mitochondrial function and suppressing endoplasmic reticulum stress. J. Biol. Chem. 2018, 293, 4735-4751. [CrossRef] 